\title{
Cigarette purchase and accessibility among children in a developing country. A study among in-school youth in Lagos state, Nigeria Oluwakemi Ololade Odukoya ${ }^{1}$, Olanrewaju Onigbogi ${ }^{1}, C_{\text {Chife Jacob }}{ }^{1}, K_{0}$ lawole Okuyemi ${ }^{2}$
}

\begin{abstract}
INTRODUCTION Tobacco use remains a significant public health challenge in many low and middleincome countries, including Nigeria. Cigarette accessibility drives experimentation and use. The objectives of this study were to assess the experiences of youth, regarding cigarette purchase and accessibility within their community. We were particularly interested in assessing their experiences with being sent on errands to purchase cigarettes by older persons within their community.

METHODS We conducted a cross-sectional descriptive study among 899 in-school youth less than 18 years of age using a multi-stage sampling method. Data was collected using self-administered pretested questionnaire and analysed with SPSS 17.0.

RESULTS Study participants had a mean age of $13.9 \pm 1.9$ years with a roughly equal male to female ratio. More than a third (36.6\%) had been sent on an errand, to purchase cigarettes by an older person within the past year (86.6\% never smokers; $13.4 \%$ ever-smokers). Of these, majority admitted that they proceeded on the errand as directed. Persons responsible for sending the minors on errands to purchase cigarettes were primarily older friends and neighbours within the community. Of those who had been sent on such errands, about half (51.4\%) feared that they could be punished if they disobeyed. While attempting to purchase cigarettes, $59.2 \%$ admitted that no one had ever inquired about their age. Within the past year, about a third (33.6\%) had successfully purchased cigarettes for older persons within the community.

CoNCLUSIONS In implementing the national tobacco control policy, strategies to engage and educate the adults within the community must be prioritized.
\end{abstract}

\section{AFFILIATION \\ 1 College of Medicine, \\ University of Lagos, Lagos State, Nigeri \\ 2 Department of Family Medicine and Community Health, University of Minnesota, Minneapolis, USA}

\section{CORRESPONDENCE TO}

Oluwakemi Ololade Odukoya, College of Medicine, University of Lagos, Ishaga road, 12003 Idiaraba, Nigeria, Email: drolukemiodukoya@yahoo. com

\section{KEY WORDS}

Accessibility, cigarettes, purchase, errands

\section{INTRODUCTION}

Tobacco use among youth remains a significant global public health challenge especially in low and middle Income countries (LMICs). The vast majority of smokers begin using tobacco products well before the age of 18 years ${ }^{1,2}$. If current trends continue, a lifetime of tobacco use would result in the deaths of 250 million children and young people alive today, most of them in low-and middle-income countries (LMICs) ${ }^{3}$.

In recent years, the tobacco control community has shifted its focus to LMICs, which are becoming a major market for tobacco companies seeking to expand their profits and compensate for dwindling markets in higher-income countries ${ }^{4}$. Many countries in sub-Saharan Africa are in the first stage of the tobacco epidemic ${ }^{4}$. Nigeria, the most populous country in Africa, with an estimated $44 \%$ of her population under the age of 18 years, remains an attractive market for the tobacco industry ${ }^{4,5}$. The 2008 Global Youth Tobacco Survey (GYTS) conducted among children aged 13-15 years in five sites across Nigeria showed rates of smoking experimentation ranging from $4.7 \%$ in Ibadan (South Western region) to $16.1 \%$ in Kano (North central region), while current smoking rates ranged from $0.3 \%$ to $11.4 \%$ among girls and boys in Kano state respectively.6 Furthermore, $2.9 \%$ of girls in Ibadan and up to $17.8 \%$ of girls in Lagos state who had never smoked cigarettes reported that they were likely to initiate cigarette smoking within the next year ${ }^{6}$. Availability and accessibility of different types of tobacco products to youth have been identified as an important determinant of tobacco use ${ }^{7}$. Reducing the availability and accessibility of cigarettes to young people can significantly reduce youth smoking. While there is paucity of data from many African countries, studies in more developed countries showed that youth who perceived cigarettes as 
relatively easy to get, were more likely to become regular smokers compared with those who perceived cigarettes as more difficult to obtain ${ }^{7,8}$. Another study analysing youth tobacco access policies, compliance, and enforcement concluded that aggressive and comprehensive approaches to limiting youth access lead to significant reductions in youth smoking ${ }^{9}$.

In order to reduce or eliminate tobacco use globally, the World Health Organization facilitated the Framework Convention on Tobacco Control (FCTC), the first public health treaty endorsed by more than 180 countries worldwide, and also ratified by Nigerian Government ${ }^{10}$. Article 16 of the WHO FCTC treaty focuses on "Sales to and by children" and states that "parties should adopt and implement effective legislative, executive, administrative or other measures at the appropriate government level to prohibit the sales of tobacco products to persons under the age set by domestic law, national law or eighteen"10. In May 2015, Nigeria passed the long awaited National Tobacco Control Bill (NTCB). This bill is an improvement on the previously enacted Tobacco Control Act (TCA) of 1990, which made no provisions for restrictions on sales to underage children ${ }^{11}$. The recently passed NTCB clearly prohibits the sale of cigarettes to and by children. However, it is not yet clear how this law will be effectively implemented.

In many parts of Africa, it is culturally acceptable for older people to send younger ones on errands. Studies in some high-income countries cite common sources of access to cigarettes among youth, as retailers, peers, vending machines, and the internet ${ }^{12-15}$. In African LMIC's, only few studies have examined community sources of cigarette access among children, particularly as it relates to the often prevailing culture of being sent on errands by adults. A child who is sent on an errand to purchase cigarettes has easier access to cigarettes and may be more likely to experiment with smoking. This might hold true in a country like Nigeria where a majority of the youth are never-smokers ${ }^{6}$. One study among youth in Lagos, Nigeria incidentally found that underage youth who had been sent to purchase cigarettes by older family members were more likely to experiment with smoking, however this study was not limited to children less than 18 years and did not assess their reported attempts at the successful purchase of the cigarettes when sent ${ }^{16}$. We therefore set out to assess the experiences of underage adolescents regarding the purchase of cigarettes and cigarette accessibility within their community. We were specifically interested in looking at the experiences of young peoples' particularly as it relates to their being sent on errands to purchase cigarettes by older persons. We also assessed their reported attempts at purchasing cigarettes and the factors associated with these among the youth.

\section{METHODS}

\section{Description of the Study Area}

Lagos state is the commercial capital of Nigeria and the most densely populated state in the country. Mushin Local Government Area (LGA), an urban area, is one of the oldest LGAs in the state and is located at the geometrical center of Lagos metropolis, southwestern Nigeria. Mushin LGA consists of 14 wards, had 633,009 inhabitants at the 2006 Census and its inhabitants are mostly Yoruba people ${ }^{17}$. Continuing expansion since the 1950's have led to problems of overcrowding, inadequate housing, and poor sanitation within the LGA.

\section{Study design and sample size estimation}

This cross-sectional descriptive study was carried out among students less than 18 years enrolled in public and private schools in the Mushin LGA. Selected schools had to be co-educational secondary schools and registered with the Lagos state Ministry of Education. In Mushin LGA, there were 10 public Junior (JSS) and 6 senior secondary (SSS) schools and 48 private schools that met these criteria. Three schools were randomly selected for the study, one public junior secondary school, one public senior secondary school and one private school. The minimum sample size was determined using a standard normal deviation of 1.96 , a p of 0.5 for maximum variability, margin of error of 0.05 and a design effect of 2 . The minimum sample size calculated was 769. Giving allowances for a $20 \%$ non-response rate, this was increased to 922 .

\section{Sampling Method, data collection tools and techniques}

A multistage sampling technique was used to select the respondents. Eligible students had to be less than 18 years of age and registered students of the selected schools. After selecting eligible schools in the first stage, then, depending on the class size, one or two classes in each arm of the school were randomly selected. In each selected class, all the eligible and consenting students available in school at the time of data collection were interviewed after an informed consent and verbal verification of age. Data was collected using a pre tested self-administered anonymous questionnaire assessing information on respondents' socio-demographic characteristics, access to cigarettes and experiences regarding the purchase of cigarettes within their community. The questionnaire was developed by the authors after a review of relevant literature and based on their local knowledge of cigarette accessibility within the community. The questionnaire had four sections. It elicited information on the respondents' socio-demographic data, type of school and their receipt of personal monetary allowances; their experiences regarding being sent on errands 
to purchase cigarettes by older persons within the community; their opinions and experiences regarding cigarette accessibility, attempts at purchase and actual cigarette purchase by the respondents; The final section elicited information on their smoking habits, future intention to smoke and the smoking habits of close family members.

Data was collected anonymously in class during school hours but without teachers present and each survey took approximately 10-15 minutes to complete. Data collection took place in June 2013. Students in JSS3 and SS3 were not included in the study as they were unavailable at the time of the survey because they had written their final year exams for the academic year. Ethical approval was obtained from the Health and Ethics Research Committee of the Lagos University Teaching Hospital and permission from the principal of each school before the start of the study.

\section{Measures}

Children were asked if they had been sent to purchase cigarettes by an older person (not peers) in the past year. Those who answered in the affirmative were classified as having "been sent" on errands to purchase cigarettes, while those who did not answer in the affirmative were classified and not being sent on such errands. Secondly, respondents were asked if they had successfully purchased a cigarette from a cigarette vendor within the past year. Those who answered in the affirmative were considered to have successfully purchased cigarettes, while these who did not, were considered not to have successfully purchased cigarettes.

\section{Data Analysis}

The data was entered using Epi Info version 3.5.1 and analyzed using SPSS 17.0 statistical package. A bivariate analysis was conducted with two dependent variables. First, respondents were classified into two groups based on their experiences of having ever been sent by older relatives or older friends to purchase cigarettes i.e. those who had ever had the experience of being sent to purchase cigarettes were placed in one category while those who had never had such experience were placed in the second category. Second, we categorised the students based on their experiences of having ever successfully purchasing a cigarette, that is, those who had ever successfully purchased cigarettes and those who has never successfully purchased cigarettes. Thereafter, a bivariate analysis was conducted for each of the two outcome variables.

Variables that were statistically significant in the bivariate analysis were entered into a multivariate model. Adjusted odds ratios and $95 \%$ confidence intervals were calculated. $p$ values of $<0.05$ were considered statistically significant.

\section{RESULTS}

Of the 922 questionnaires administered, only 899 were appropriately filled and subsequently analysed giving a response rate of $97.5 \%$. Socio-demographic characteristics: The mean age of the respondents was $13.9 \pm 1.9$ years. There were slightly more males than females. Respondents were mostly of Yoruba ethnicity and $65.3 \%$ were in public schools. Majority (71.9\%) received personal monetary allowance, which was mostly less than N1000 (approximately \$5) per month. (Table 1) Respondents' experiences regarding the purchase of cigarettes and its accessibility among youth within the community: More than a third (36.6\%) had been sent to purchase cigarettes by an older person within their community in the past year, $(86.6 \%$ never smokers; $13.4 \%$ ever-smokers $p<0.001)$. Of these, majority admitted that they went on the errand as directed. Persons responsible for sending the children were primarily older friends and neighbours within the community. Of those who had been sent on such errands, about half (51.4\%) feared that they could be punished if they disobeyed. While attempting to purchase cigarettes, $59.2 \%$ admitted that no one had ever inquired about their age. About a third (33.6\%) had successfully purchased cigarettes for elders within the community while a smaller proportion (10.5\%) had successfully purchased cigarettes for themselves or for someone within their age bracket. Other details are shown in Table 2 . Factors associated with being sent on an errand to purchase cigarettes the actual purchase of cigarettes by the children: Factors Associated with Being Sent on an errand to purchase cigarettes and the actual purchase of cigarettes by the children. Religion, type of school, receipt of personal monetary allowance, having a household member that smokes and the perception of likelihood of being punished for disobeying such errands. The multivariate model showed that those who receive personal monetary allowance, had a close friend or household member that smokes, had experimented with smoking, had ever been offered a cigarette and had the perception that they could be punished for not obeying adults who send them to purchase the cigarettes were significantly more likely to purchase cigarettes. (Tables $4 \& 5$ )

Table 3 also shows that respondents in public schools, those who receive personal monetary allowance, those who had ever experimented with smoking, and those whose household members or close friends smoke were more likely to be sent on errands to purchase cigarettes. In addition, those who think they'll be punished for disobeying were also more likely to 
be sent on such errands. A multivariate analysis showed that there was a relationship between being sent on errands to purchase cigarettes and having a household member that smokes; having experimented with cigarettes; ever been offered a cigarette; and the perception of being punished for not obeying adults who send children to purchase cigarettes. (Tables 4\&5)

Table 1: Socio demographic characteristics of the respondents

$\begin{array}{ll}\text { Socio demographic variables }(n-899) & \text { Frequency }(\%) \\ \qquad 11 & \text { Age (in years) } \\ 11-13 & 27(3.0) \\ 14-16 & 371(41.3) \\ >16 & 421(46.8) \\ & 80(8.9)\end{array}$

Gender

13.8(1.9)

$457(50.8)$

Male

442(49.2)

Female

$519(57.7)$

Christianity

$380(42.3)$

Islam

Ethnicity

Yoruba

$615(68.4)$

Igbo

184(20.5)

Hausa

42(4.7)

Other*

$58(6.5)$

Type of School

Private

$312(34.7)$

Public

$587(65.3)$

Class

Year 7

$230(25.6)$

Year 8

$220(24.5)$

Year 10

$279(31.0)$

Year 11

170(18.9)

Receives personal monetary allowance

$717(79.8)$

\section{Amount received monthly (Naira)}

$<500$

282(31.4)

500-999

$270(30.0)$

1000-1499

24(2.67)

$1500-2000$

$21(2.3)$

$>2000$

$120(13.4)$
Table 2: Respondents experiences regarding the purchase of cigarettes and its accessibility among minors within the community.

Variables

\section{Respondent has:}

Ever been seen with a cigarette

813(90.4)

Ever touched a cigarette

454(50.5)

Been sent to purchase cigarettes for an older person within

$329(36.6)$

the past year

Respondents who usually go when sent $(n=329)$

$250(75.9)$

Persons responsible for sending the minor on errands to purchase cigarettes $(n=329)$

$\begin{array}{lc}\text { Father } & 18(5.5) \\ \text { Siblings } & 30(9.1) \\ \text { Older friend } & 45(13.7) \\ \text { Neighbour } & 208(63.2) \\ \text { Others } & 28(8.5)\end{array}$

Average frequency of purchase of cigarettes within the past year $(n=250)$

$\begin{array}{ll}\text { Almost everyday } & 57(22.8) \\ \text { About once or twice weekly } & 96(38.4) \\ \text { About once or twice in a month } & 91(36.4) \\ \text { About once or twice every other month or less } & 6(2.4)\end{array}$

Age at which child was first sent to purchase a cigarette $(n=329)$ $<7$

62(18.8)

$8-10$

$107(32.5)$

$11-13$

97(29.5)

14-16

$49(14.9)$

$>16$

$14(4.3)$

Mean (SD)

$11.1 \pm 2.8$

Respondent thinks he/she will be punished if they refuse to purchase cigarettes when sent by an older person $(n=329)$

When attempting to purchase cigarettes, does anyone inquire about your age? $(n=250)$

$\begin{array}{ll}\text { Yes, always } & 49(19.6) \\ \text { Yes, sometimes } & 53(21.2 \\ \text { No, Never } & 148(59.2)\end{array}$

No, Never

148(59.2)

When attempting to purchase cigarettes, respondent has been denied purchase because of age $(n=250)$

Yes, always

43(17.2)

Yes, sometimes

$44(17.6$

No, Never

$163(65.2)$

Respondent who have successfully purchased a cigarette within the past year either for themselves or for others

$302(33.6)$ $(n=899)$

Respondent who have successfully purchased cigarette

$94(10.5)$

either for themselves or for someone within their age bracket within the past month $(n=899)$

Respondent believes that cigarettes are easily accessible to youth within the community $(n=899)$

Respondent reports that cigarettes are sold on the school premises or within 100 meters from the school $(n=899)$
$340(37.8)$

$387(43.1)$ 
Research Article

\section{Table 3: Smoking pattern among the respondents and smoking status of close friends and relatives}

\section{Tariables}

Smoking status

Ever-smoker

Current smoker

Never smoker

Frequency of smoking $(n=64)$

Daily

Weekly

Monthly

Rarely

Age at smoking initiation $(n=64)$

$<10$

$11-13$

$14-16$

$>16$

Mean age(SD)

Usual sources of cigarettes * Multiple response

Self-purchase

From parties

From friends

From older family members

Likelihood of smoking initiation within the next year among never-smokers ( $n=835)$

Believes that his/her religion disapproves of smoking $(n=899)$

494(59.2)

At least one close friend smokes $(n=899)$

135(16.2)

At least one household member smokes $(n=899)$

Father smokes $(n=899)$

$36(4.3)$

Mother smokes $(n=899)$

17(2.0)

$40(4.8)$

Any sibling smokes $(n=899)$

$149(17.8)$

Ever been offered a cigarette by anyone $(n=899)$

Accepted the cigarette offered $(n=149)$

$47(31.5)$

Person who offered cigarette? $\quad(n=149)$

Cigarette sales rep

$40(26.8)$

Peer

$30(20.1)$

Older friend

$45(30.2)$

Older family member

Parent

14(9.4)

Others 
Research Article

Table 4: A bivariate analysis of the factors associated with the purchase of cigarettes and being sent to purchase cigarettes among the respondents.

\begin{tabular}{|c|c|c|c|c|c|c|c|c|c|}
\hline $\begin{array}{l}\text { Socio- } \\
\text { demographic } \\
\text { variables } \\
(\mathbf{n} \mathbf{8 9 9 )}\end{array}$ & $\begin{array}{l}\text { Purchased a } \\
\text { cigarette } \\
\text { (n-302) }\end{array}$ & $\begin{array}{l}\text { Not } \\
\text { purchased } \\
\text { a cigarette } \\
(n-597)\end{array}$ & $\begin{array}{l}\text { Chi- } \\
\text { square }\end{array}$ & p value & $\begin{array}{l}\text { Been sent to } \\
\text { purchase } \\
\text { cigarettes } \\
\text { (n-329) }\end{array}$ & $\begin{array}{l}\text { Not been sent } \\
\text { to purchase } \\
\text { cigarettes } \\
(n-570)\end{array}$ & p value & Chi square & Total \\
\hline $\begin{array}{l}\text { Mean age (in } \\
\text { years) }\end{array}$ & $13.83(1.81)$ & $13.90(1.91)$ & 0.49 & 0.623 & $13.81(1.86)$ & 13.92(1.88) & 0.422 & 0.80 & $13.9(1.9)$ \\
\hline \multicolumn{10}{|c|}{ Gender } \\
\hline Male & $158(34.6)$ & $299(65.4)$ & & & $173(37.9)$ & $284(62.1)$ & & & $457(100)$ \\
\hline Female & $144(32.6)$ & $298(67.4)$ & 0.40 & 0.527 & $156(35.3)$ & $286(64.7)$ & 0.425 & 0.64 & $442(100)$ \\
\hline \multicolumn{10}{|c|}{ Religion } \\
\hline Christianity & $191(36.8)$ & $328(63.2)$ & & & $200(38.5)$ & $319(61.5$ & & & $519(100)$ \\
\hline Islam & $111(29.2)$ & $269(70.8)$ & 5.67 & 0.017 & $129(33.9)$ & $251(66.1)$ & 0.158 & 1.99 & $380(100)$ \\
\hline \multicolumn{10}{|c|}{ Ethnicity } \\
\hline Yoruba & $221(35.9)$ & $394(64.1)$ & & & $223(36.3)$ & $392(63.7)$ & & & $615(100)$ \\
\hline Igbo & $54(29.3)$ & $130(70.7)$ & & & $73(39.7)$ & $111(60.3)$ & & & $184(100)$ \\
\hline Hausa & $13(31.0)$ & $29(69.0)$ & & & 13(31.0) & $29(69.0)$ & & & $42(100)$ \\
\hline Other ${ }^{*}$ & $14(24.1)$ & $44(75.9)$ & 5.45 & 0.141 & $20(34.5)$ & $38(65.5)$ & 0.689 & 1.47 & $58(100)$ \\
\hline \multicolumn{10}{|c|}{ Type of School } \\
\hline Private & $88(28.2)$ & $224(71.8)$ & & & $99(31.7)$ & $213(68.3)$ & & & $312(100)$ \\
\hline Public & $214(36.5)$ & $373(63.5)$ & 6.22 & 0.013 & $230(39.2)$ & $357(60.8)$ & 0.027 & 4.88 & $587(100)$ \\
\hline \multicolumn{10}{|l|}{ Class } \\
\hline Junior Secondary & $157(70.0)$ & $293(130)$ & & & $167(74.3)$ & $283(125.7)$ & & & $450(100)$ \\
\hline Senior Secondary & $145(63.7)$ & $304(136.3)$ & 4.73 & 0.193 & 162(71.9) & $287(128.1)$ & 0.825 & 0.90 & $449(100)$ \\
\hline \multicolumn{10}{|c|}{ Receives personal monetary allowance } \\
\hline Yes & $262(36.5)$ & $455(63.5)$ & & & $274(38.2)$ & $443(61.8)$ & & & $717(100)$ \\
\hline No & $40(22.0)$ & $142(78.0)$ & 13.80 & 0.000 & $55(36.2)$ & $127(69.8)$ & 0.046 & 4.00 & $182(100)$ \\
\hline \multicolumn{10}{|c|}{ Smoking status } \\
\hline Ever smoker & $52(81.3)$ & 12(18.8) & & & $44(68.7)$ & $20(31.3)$ & & & $64(100)$ \\
\hline Never smoker & $250(29.9)$ & $585(70.1)$ & 70.153 & 0.000 & $285(34.1)$ & $550(65.9)$ & 0.000 & 30.70 & $835(100)$ \\
\hline \multicolumn{10}{|c|}{ Any household member smokes } \\
\hline Yes & $57(61.3)$ & $36(38.7)$ & & & $56(60.2)$ & $37(39.8)$ & & & $93(100)$ \\
\hline No & $245(30.4)$ & $561(69.6)$ & 35.672 & 0.000 & $273(33.9)$ & $533(66.1)$ & 0.000 & 24.94 & $806(100)$ \\
\hline Yes & $36(67.9)$ & $17(32.1)$ & & & $33(62.3)$ & $20(37.7)$ & & & $53(100)$ \\
\hline No & $266(31.4)$ & $580(68.6)$ & 29.757 & 0.000 & $296(35.9)$ & $550(65.0)$ & 0.000 & 15.99 & $846(100)$ \\
\hline \multicolumn{10}{|c|}{ Sibling smokes } \\
\hline Yes & $21(52.5)$ & $19(47.5)$ & & & $23(62.3)$ & $17(42.5)$ & & & $40(100)$ \\
\hline No & $281(327)$ & $578(67.3)$ & 6.708 & 0.010 & $306(35.6)$ & $553(64.4)$ & 0.005 & 7.88 & $856(100)$ \\
\hline \multicolumn{10}{|c|}{ Close friend smokes } \\
\hline Yes & $87(64.4)$ & $48(35.6)$ & & & $82(60.7)$ & $53(39.3)$ & & & $135(100)$ \\
\hline No & $215(28.1)$ & $549(71.9)$ & 67.779 & 0.000 & 247 & $517(67.7)$ & 0.000 & 39.90 & $517(100)$ \\
\hline \multicolumn{10}{|c|}{ Ever been offered a cigarette } \\
\hline Yes & $98(65.8)$ & $51(34.2)$ & & & $94(63.1)$ & $55(36.9)$ & & & $149(100)$ \\
\hline No & $204(27.2)$ & $543(72.8)$ & 82.902 & 0.000 & $235(31.3)$ & $515(68.7)$ & 0.000 & 0.15 & $405(100)$ \\
\hline \multicolumn{10}{|c|}{ Religion frown at smoking } \\
\hline Yes & 168(34.0) & $326(66.0)$ & & & $178(36.0)$ & $316(64.0)$ & & & $494(100)$ \\
\hline
\end{tabular}


Research Article

\begin{tabular}{|c|c|c|c|c|c|c|c|c|c|}
\hline No & $134(33.1)$ & $271(66.9)$ & 0.085 & 0.771 & $151(37.3)$ & 254(62.7) & 0.698 & 0.15 & $405(100)$ \\
\hline \multicolumn{10}{|c|}{ Likelihood of smoking initiation within the next year } \\
\hline Yes & $45(67.2)$ & $22(32.8)$ & & & $39(58.2)$ & 28(41.8) & & & $67(100)$ \\
\hline No & 257(30.9) & $575(69.1)$ & 36.575 & 0.000 & $290(34.9)$ & $542(65.1)$ & 0.000 & 14.57 & $832(100)$ \\
\hline \multicolumn{10}{|c|}{ Perception of penalties for not purchasing cigarettes when sent } \\
\hline $\begin{array}{l}\text { Thinks he'll be } \\
\text { punished }\end{array}$ & 135(79.9) & $34(20.1)$ & & & 158(93.5) & $11(6.5)$ & & & $169(100)$ \\
\hline $\begin{array}{l}\text { Does not think he'll } \\
\text { be punished }\end{array}$ & $167(22.9)$ & $563(77.1)$ & 199.900 & 0.000 & $171(23.4)$ & $559(76.6)$ & 0.000 & 290.35 & $730(100)$ \\
\hline
\end{tabular}

Table 5: Factors associated with cigarette purchase by minors and beinfsent on errands to purchase cigarettes by minors.

\begin{tabular}{|c|c|c|c|c|c|c|}
\hline \multirow[t]{2}{*}{ Variables } & $\begin{array}{l}\text { Sent to purchase } \\
\text { cigarettes by older } \\
\text { persons }\end{array}$ & & $\begin{array}{l}\text { Purchased } \\
\text { cigarettes }\end{array}$ & & & \\
\hline & Odds ratio & $95 \% \mathrm{CI}$ & p value & Odds ratio & $95 \% \mathrm{CI}$ & p value \\
\hline Being in a public school & 1 & $299(65.4)$ & & 1 & & \\
\hline Being in a private school & 0.822 & $0.57-1.19$ & 0.294 & 0.77 & $0.534-1.11$ & 0.164 \\
\hline
\end{tabular}

Receives personal monetary allowance

No

Yes

$0.92-2.28$

0.11

1

Smoking status of close

friend

None of respondents close

friend's smokes

At least a close friend

$0.80-2.64$

0.222

1.38

$1.05-2.53$

0.014

smokes

At least one household member smokes

No

1

Yes

1.70

$1.09-2.90$

0.041

2.08

$1.21-3.58$

0.008

Respondent's smoking status

Never smoked cigarettes $\quad 1$

Ever smoked cigarettes $\quad 2.09$

$1.04-4.20$

0.040

\section{Offered cigarette}

Never been offered a

1

cigarette

Has been offered a cigarette

2.15

$1.33-3.48$

0.002

.617

$1.65-4.25$

0.000

Punished

Does not think he'll be $\quad$ l

punished if

\begin{tabular}{|c|c|c|c|c|c|c|}
\hline Thinks he'll be punished & 45.32 & $23.80-86.35$ & 0.000 & 13.62 & $8.72-21.28$ & 0.000 \\
\hline \multicolumn{7}{|c|}{ Religion } \\
\hline Christianity & - & - & - & 1 & & \\
\hline Islam & - & - & - & 1.54 & $1.08-2.09$ & 0.17 \\
\hline
\end{tabular}




\section{DISCUSSION}

This is one of a limited number of studies that have assessed cigarette purchase and accessibility among underage adolescents in Nigeria. More than a third (33.6\%) of the underage youth successfully purchased cigarettes within their community within the past year. Of these, majority stated that no retailer or cigarette vendor had ever inquired of their age before purchase. For years, the tobacco industry in Nigeria has claimed that it does not support the sale of cigarettes to persons less than 18 years ${ }^{18}$ and it is common to see cigarette vendors/retailers with branded signs prohibiting the sales to individuals less than 18 years in the country. However, this study demonstrated that majority of the Tobacco Industry (TI) vendors sell cigarettes to youth without verifying their age even verbally as $59.2 \%$ of the youth reported that no one had ever inquired of their age before selling cigarettes to them. It is unclear whether these vendors were aware of the need for age verification before purchase, or whether they simply choose not to do so. These findings are particularly important, as Nigeria has recently passed the Nigeria Tobacco Control Bill (NTCB) banning the sale of cigarettes to people less than 18 years. Other countries like Italy, United states and New Zealand, have also reported challenges with implementing laws banning sales to minors even where they exist ${ }^{19-22}$. It behoves on the Nigerian government to put in place measures that will ensure that these laws are not merely enacted but appropriately enforced, otherwise the laws may not have the desired effects

of protecting youth from the dangers of tobacco use.

Cigarette accessibility drives experimentation and use and policies designed to reduce youth access to tobacco can have a significant impact on adolescent smoking rates $^{7,23}$. In this study, we were particularly interested in the sources of cigarette access as it relates to the cultural context of older adults and family/community members sending youth on errands to purchase cigarettes. We found that more than one in three $(36.6 \%)$ of the youth had been sent to purchase cigarettes by older adults within the past year. Of those who had been sent on such errands, many of them were sent by either household or community members. Neighbours formed the bulk of the people who initiated these errands (63.2\%). In more developed countries, typical sources of cigarette access may not include community sources like neighbours ${ }^{12}$. The case appears to be different in cultural African settings like Nigeria ${ }^{24}$. In implementing programs and policies designed to reduce cigarette accessibility in these and similar settings, it is important to look beyond the usual sources of cigarettes and the child's immediate nuclear family and focus on educating other adults within the community on the dangers of childhood tobacco use and the need to limit cigarette access to kids. The current study also showed that those who were sent on errands to purchase cigarettes were sent relatively frequently as $60.2 \%$ were sent either every day or at least once or twice a week. Also, many of them believed that cigarettes are easily accessible to youth within their community. We also observed that more respondents who had been sent on such errands reported that they were likely to initiate cigarette smoking within the coming year and this is in agreement with other studies where reducing access has been recommended to curb smoking susceptibility ${ }^{25-27}$. In a country like Nigeria, where many youth are never-smokers, 6 sending under-aged youth to purchase cigarette increases their accessibility to cigarettes and might play a factor in cigarette experimentation and initiation ${ }^{24}$.

In this study, we found that majority of the youth that were sent to purchase cigarettes were successful in purchasing cigarettes. This is not surprising because in many African countries, respect for elders is the cultural norm ${ }^{24,28}$. More than half of the youth felt that they would be punished if they did not go on such errands. The fear of punishment from family and community members may play a major role in their attempt at purchasing cigarettes ${ }^{28}$, further emphasizing the fact that a focus on educating adults within the community needs to be prioritized.

Studies in other parts of the world have reported an association between cigarette accessibility and experimentation ${ }^{7,25,27}$. Our findings agree with this assertion, as sending children on errands to purchase cigarettes and actual purchase attempts were significantly associated with smoking experimentation.

In looking at the factors associated with cigarette purchase by the children, either for themselves or for older adults within the community, we found that students who received personal monetary allowance were 22 times more likely to purchase cigarettes. This might be an indicator of the child's access to disposable income. Similar findings have been reported in China and India ${ }^{29,30}$ it might be worthwhile to consider encouraging parents and guardians to limit the disposable income of their wards to help reduce access to cigarettes.

The perception of being punished also comes to play, as kids who thought they would be punished were more likely to either be sent on errands to purchase cigarettes or to successfully purchase cigarettes. In many societies in Africa, the cultural norm of respect for elders is rife, and the possibility of punishment for those who disobey elders exists ${ }^{30}$. So when 
youth are sent on such errands they might have no choice but to obey for fear of reprimand or punishment. This supports the findings reported in a similar study by researchers in Southern Nigeria ${ }^{24}$. In African settings, where the culture of respect for elders is paramount, the focus ought to be shifted to educating the adults and instituting stiff penalties to adults for providing undue cigarette access to youth within their communities.

This study has some limitations. First, the cross-sectional nature of this study does not allow us to determine a temporal association and we cannot say for sure whether the fact that these students were sent on such errands or had purchased cigarettes predisposed them to the factors listed or vice versa. Second, the possibility of recall bias may have occurred. Nevertheless, this study sheds light on the experiences of underage youth in this setting regarding cigarette purchase. In implementing the newly passed NTCB, policy makers should consider these findings and design strategies to ensure effective implementation of the NTCB for the protection of young people from the dangers of tobacco use.

\section{REFERENCES}

1. World Health Organisation. (WHO) 2008 Report on the global tobacco epidemic. Available from: http://www.who.int/tobacco/ mpower/mpower_report_full_2008.pdf. (accessed June 2015)

2. Center for Disease Control. Preventing tobacco use among youth and young adults. Centers for Disease Control and Prevention; 2012.

3. World Health Organisation. About youth and tobacco. Availble from: http://www.who.int/tobacco/research/youth/youth/en/ (accessed June 2015)

4. Drope J. Tobacco Control in Africa. People, Politics and Policies. Available from: http://www.idrc.ca/EN/Resources/Publications/ openebooks/510-6/index.html\#page_29 (accessed June 2014)

5. Population Reference Bureau. 2014 World population data sheet. Available from: http://www.prb.org/pdf14/2014-world-populationdata-sheet_eng.pdf (accessed June 2015)

6. Ekanem I (2008). A report for the Nigeria global youth tobacco survey. Available from: http://www.afro.who.int/dnc/databases/ gyts/reports/NIGERIA_GYTS\%202008.pdf (accessed May 2013)

7. Doubeni, Chyke A., Wenjun Li, Hassan Fouayzi, and Joseph R. DiFranza. "Perceived accessibility as a predictor of youth smoking." The Annals of Family Medicine 6, no. 4 (2008): 323330 .

doi: 10.1370/afm.841.

8. Gallus, Silvano, Irene Tramacere, Piergiorgio Zuccaro, Paolo Colombo, and Carlo La Vecchia. "Tobacco sales to minors in Italy." Tumori 95, no. 3 (2008): 283-285.

9. Lantz PM, Jacobson PD, Warner KE, Wasserman J, Pollack HA, Berson J, Ahlstrom A. Investing in youth tobacco control: a review of smoking prevention and control strategies. Tobacco control. 2000 Mar 1;9(1):47-63.

10. World health organization. WHO Framework Convention for Tobacco Control. Available from: http://whqlibdoc.who.int/publicat ions/2003/9241591013.pdf?ua=1. (accessed June 2014)
11. Campaign for tobacco free kids. Legislation-Nigeria details. Nigeria tobacco control Act 1990. Available from: http://www. tobaccocontrollaws.org/legislation/country/nigeria/laws/desc. (accessed May 2015)

12. Campaign for tobacco free kids. Where do kids get their cigarettes from? https://www.tobaccofreekids.org/research/factsheets/ pdf/0073.pdf Accessed January 2015

13. Kann, L., Kinchen, S., Shanklin, S. L., Flint, K. H., Kawkins, J., Harris, W. A., ... \& Zaza, S. Youth risk behavior surveillance-United States, 2013.MMWR Surveill Summ, 2014, 63(Suppl 4), 1-168.

14. Johnston, L. D., O’Malley, P. M., \& Terry-McElrath, Y. M. Methods, locations, and ease of cigarette access for American youth, 19972002. American journal of preventive medicine, 2004, 27(4), 267276.

15. U.S. Dept of Health \& Human Services, 2003 National Survey on Drug Use and Health, September 9, 2004. Available from: http://oas.samhsa.gov/NHSDA/2k3NSDUH/2k3results.htm\#ch4 (accessed June 2015)

16. Odukoya, O. O., Odeyemi, K. A., Oyeyemi, A. S., \& Upadhyay, R. P. Determinants of smoking initiation and susceptibility to future smoking among school-going adolescents in Lagos state, Nigeria. Asian Pac J Cancer Prev, 2013,14(3), 1747-53.

17. National Bureau of Statistics. Federal Government of Nigeria 2006 population census. Available from: www.nigerianstat.gov.ng. (accessed November 2014)

18. British American Tobacco Nigeria. Youth Smoking Prevention. Available from: http://www.batnigeria.com/group/sites/BAT_ 7YKM7R.nsf/vwPages WebLive/DO7YLFSS?opendocument (accessed June 2015)

19. Williams, R. J., Kobayashi, L., Fujimoto, T., Swartz, K., Whitehead, T. K., \& Bonifacio, N. Trends in Underage Tobacco Sales: An Update on the Past Decade of Compliance Checks in Hawai 'i. Hawaili Journal of Medicine \& Public Health, 2014, 73(10), 315.

20. DiFranza, J. R., \& Dussault, G. F. The federal initiative to halt the sale of tobacco to children-the Synar Amendment, 1992-2000: lessons learned. Tobacco Control, 2005, 14(2), 93-98.

21. Lugo, A., Asciutto, R., Pacifici, R., Colombo, P., La Vecchia, C., \& Gallus, S. Smoking in Italy 2013-2014, with a focus on the young. Tumori. 2015 Sep 9;101(5):529-34. doi: 10.5301/tj.5000311.

22. Marsh, L., Gray, A., McGee, R., Newcombe, R., \& Patterson, R. Access to cigarettes by young New Zealand smokers: little change from 2000 to 2008.Australian and New Zealand journal of public health, 2012 Oct;36(5):415-20. doi: 10.1111/j.1753-6405.2012.00909.x

23. Spivak, A. L., \& Monnat, S. M. Prohibiting juvenile access to tobacco: Violation rates, cigarette sales, and youth smoking. International Journal of Drug Policy. 2015 Sep;26(9):851-9. doi: 10.1016/j.drugpo.2015.03.006

24. Egbe, C. O., Petersen, I., Meyer-Weitz, A., \& Asante, K. O. An exploratory study of the socio-cultural risk influences for cigarette smoking among Southern Nigerian youth. BMC public health, 2014 Nov 22;14:1204. doi: 10.1186/1471-2458-14-1204

25. Bonnie RJ, Stratton K, Kwan LY, editors. Public Health Implications of Raising the Minimum Age of Legal Access to Tobacco Products. National Academies Press; 2015 Jul 23.

26. Braverman MT, Aarø LE. Adolescent smoking and exposure to tobacco marketing under a tobacco advertising ban: findings from 2 Norwegian national samples. American Journal of Public Health. 
Research Article

2004 Jul;94(7):1230-8.

27. Stead LF, Lancaster T. A systematic review of interventions for preventing tobacco sales to minors. Tobacco Control. 2000 Jun 1;9(2):169-76.

28. Bradley, R. H., \& Corwyn, R. F. Caring for children around the world: A view from HOME. International Journal of Behavioral Development, 2005, 29(6), 468-478.

29. Ma, J., Zhu, J., Li, N., He, Y., Cai, Y., Qiao, Y., ... \& Wang, Z. (Cigarette smoking in Chinese adolescents: importance of controlling the amount of pocket money. Public health, 2013 Jul;127(7):687-93. doi: 10.1016/j.puhe.2013.04.016

30. Kumar, V., Talwar, R., Roy, N., Raut, D., \& Singh, S. Psychosocial Determinants of Tobacco Use among School Going Adolescents in Delhi, India.Journal of addiction, 2014, 2014;2014:170941.

doi: 10.1155/2014/170941.

CONFLICT OF INTEREST

The authors have completed and submitted the ICMUE Form for Disclosure of Potential Conflicts of Interest and none were reported.

FUNDING

There was no source of funding for this research.

PROVENANCE AND PEER REVIEW

Not commissioned; externally peer reviewed 